\title{
Correction to: Abstract rules for complex systems
}

\author{
Mario J. Rizzo ${ }^{1}$ iD
}

Accepted: 11 February 2021 / Published online: 4 March 2021

(c) Springer Science+Business Media, LLC, part of Springer Nature 2021

\section{Correction to: European Journal of Law and Economics https://doi.org/10.1007/s10657-020-09679-x}

The original version of this article unfortunately contained a mistake. The name of corresponding author Mario Mario Rizzo was incorrect. The correct name should be Mario J. Rizzo.

The original article has been corrected.

Publisher's Note Springer Nature remains neutral with regard to jurisdictional claims in published maps and institutional affiliations.

The original article can be found online at https://doi.org/10.1007/s10657-020-09679-x.

\section{Mario J. Rizzo}

mario.rizzo@NYU.EDU

1 New York University, New York, USA 